\section{IMPLEMENTING A TECHNICAL WRITING PROGRAM: THE ALGONQUIN EXPERIENCE}

\section{Barry Barclay}

\section{Editor's Note:}

The following is a summary of Barry Barclay's address to the National Conference, Guelph. Shortly after, he accepted the opportunity of beginning graduate studies in Texas and has been too busy to expand the summary into an article. This information, however, merits presentation because Algonquin's diploma program was the first in Canada designed specifically to train technical writers.

Further details may be obtained by writing:

Mr. Brian 0'Meara, Coordinator

Technical Writer Program

Algonquin College

Rideau Campus

200 Lees Avenue

Ottawa, Ontario

K1s OC5

In 1982 Industry's need for competent technical writers surfaced at a meeting between Algonquin College personnel and representatives of high technology firms in the Ottawa area. Subsequent meetings established that the marketplace could absorb 20 to 25 new writers every year; as a result, an Ad Hoc Advisory Committee was established in early 1982 to describe the structure and content of an appropriate technical writing program.

The committee decided on a 3 year (6-semester) plan. Students would take the first 3 of these 6 semesters in one of the regular technology programs (preferably Computer Sclence or Electronics) and transfer to the Technical Writer Program for their last 3 semesters. The committee specifled the content of these final 3 Technical Writer semesters, expressed their confidence in being able to offer summer jobs in the technical writing fleld, and began the process of obtaining provinclal approval of the program.

In late November of 1983 the program was approved by Ontario's Councll of Regents, with the proviso that the number of Technical Writer semesters be expanded from three to four.
During the next few weeks 20 students were recruited for the first (4th semester) class, and the program began early in January 1984. Individual testing and interviewing ensured that only applicants with highly developed writing skills were accepted.

Of the 20 students, 13 were direct entries from outside Algonquin College; most of these possessed advanced qualifications, typically an Engineering or Bachelor of Sclence degree. Virtually all students turned out to be strongly motivated and extremely competent.

Curriculum design was based on one highly pragmatic (and unattainable) obfective: to graduate technical writers whose need for on-the-job training would be zero. Of the 26 classroom hours per week, 14 hours were devoted to communication skills (Including technical writing, graphic design, and word processing); the remaining 12 hours were given over to technical subjects (statistics, microprocessor design, and computer architecture).

During this first semester it became clear that the economic recession would eliminate many of the summer work positions more or less guaranteed by companies represented on the Advisory Committee. However, 16 of the 19 remaining students found summer work as technical writers; of these, 4 are self-employed in a company they formed themselves. Feedback from employers 1s extremely positive: they have favourably compared the performance of the Algonquin students with the performance of experlenced writers hired recently for full-time positions.

\section{ALGONQUIN COLLEGE - TECHNICAL WRITER PROGRAM}

AD HOC ADVISORY COMMITTEE

Algonquin College - Computing Science/Electron1cs Department Algonquin College - English Department

Atomic Energy of Canada Limited

Bel1-Northern Research

Computing Devices of Canada LImited

Department of Energy, Mines, and Resources

Mitel Corporation

The NABU Network

S\&S Sof tware Limited

The Soclety for Technical Communication

Systemhouse LIm1ted 
AS PROPOSED - 1982

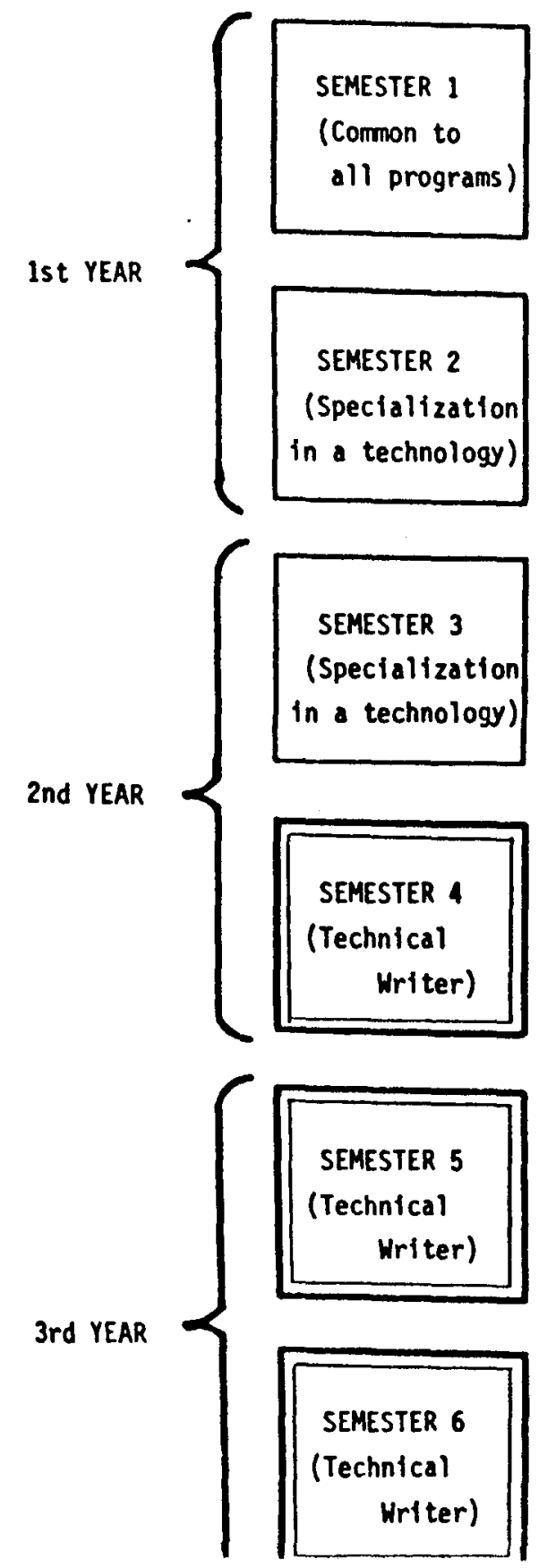

AS APPROVED - 1983

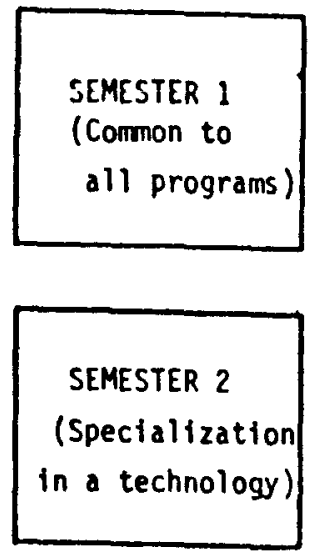

SEMESTER 3

(Technica)

Writer)

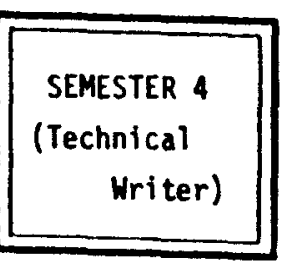

SEMESTER 5

(Technica)

Writer)

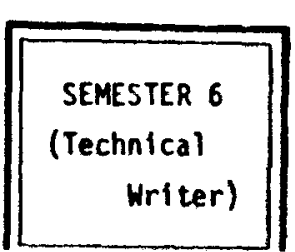

PERMANENT ADVISORY COMMITTEE

Be11-Northern Research

Gandalf Data Limited

Mitel Corporation

The NABU Network

NIVA Writing Services Limited

S $\& S$ Software Limited

The Society for Technical Communication

Systemhouse Limited

PROGRAM STRUCTURE

\section{CURRICULUM STRUCTURE}

\section{1st Semester Communication I \\ Ma themat Ics I \\ Chemistry I \\ Electricity I}

2nd Semester Comnunication II Introduction to Calculus Passive Circuits

$$
\text { Pascal }
$$

3rd Semester Technical Communication I Concepts in Mathematics Data Processing Assemby and Production Systems

4th Semester Technical Communfcation II Statistics Microprocessor A Basic Computer Archftecture

5th Semester Technical Communication III Document Planning Business Management Project Planning

6th Semester Technical Communication IV Document Management II Engineer1ng Systems
Drafting I

Physics I

Introduction to Computing

Physics II

Basic Electronics

Construction Techniques

Phsics IIIA

ONE of: Pascal

Basic Electronics

Electronics I

Word Processing Graphics I (Design)

Computer Systems

Electrical Communication Graphics II (Videotex)

Project 


\section{STUDENT PROFILE}

1. TOtAL RECRUited: 20

DROPOUTS :

1

2. SOURCES OF RECRUITMENT:

\begin{abstract}
7 transferred from within the college
\end{abstract}
13 applied as direct entries

3. EXPERIENCED PROFESSIONAL WRITERS: 8

4. DEGREES OR DIPLOMAS HELD:

Diploma, Electrical Engineering: 1

Diploma, Computer Programming: 2

Diploma, Radio and TV Arts: 1

Engineering degree and/or P.Eng.: 3

Bachelor of Science:

Bachelor of Journalism:

Bachelor of Commerce:

5. PERSONAL PROFILE:

$\begin{array}{ll}11 \text { married, } & 9 \text { single } \\ 15 \text { male, } & 5 \text { female } \\ \text { Age : } 23-24 & 6 \\ 25-28 & 10 \\ & \text { over 28 } \\ \end{array}$

\section{WRITING A CANADIAN ADAPTATION}

Dixie Stockmayer

Business Communication: Strategles and Skills by Richard C. Huseman, James M. Lahiff and John D. Hatfleld, I111no1s: Dryden Press, 1981, $431 \mathrm{PP}$.

In May 1982, when I accepted an Invitation to prepare a Canadian adaptation of the Huseman et al text, Business Communication, I was unprepared for what lay before me over the next two years: deadInes that seemed reasonable when I agreed to them initlally rushed by; a task that I anticipated might take three or four hours would take three or four times as long; changes which appeared easy were not. However, I belleve that the product justifies the planning and hard work which the adaptation required.

\section{PLANNING THE ADAPTATION}

The obvious changes required in the Canadian adaptation were, of course:

-the use of the metric system

-the replacement of American spellings, usage, and examples with Canadian material

However, I was also asked to review the text to Identify its major strengths and weaknesses with specific reference to:

1. the coverage given to particular topics or areas

-should the coverage of certain topics be expanded? abbreviated? or deleted?

-should new topic areas be expanded?

2. the number and nature of the examples in the original text -are there suffictent examples?

- to what extent are specifically Canadian examples or applicatlons needed? 